DOI: https://doi.org/10.18371/fp.4(36).2019.190246

УДК 657.6:368

\title{
АНАЛІТИЧНА ОЦІНКА ФІНАНСОВОÏ ЗВІТНОСТІ СТРАХОВИХ КОМПАНІЙ: ТЕОРЕТИЧНІ АСПЕКТИ
}

\author{
ЛУК'ЯНЕЦЬ Олена Вікторівна \\ к.е.н., дочент кафедри обліку і оподаткування \\ Черкаського інституту ДВНЗ «Університет банківської справи» \\ ORCID ID: http://orcid.org/0000-0003-2568-0375 \\ e-mail:lukjanecelena@gmail.com
}

\section{ТКАЧЕНКО Юлія Павлівна}

здобувач вищзої освіти

Черкаського інституту ДВНЗ «Університет банківської справи» e-mail: yuliya.tkachenko99@i.ua

Анотація. Успішна діяльність страховиків значною мірою залежить від довіри до них страхувальників, яка зростає за умови доступності та зрозумілості інформаціі щзодо їхньої діяльності, щчо відображається у фінансовій звітності, яка є джерелом для аналітичної оцінки фінансового стану страхової компанії на основі системи показників, щуо характеризують ї̈ фінансову стійкість, надійність та платоспроможність, та надає можсливість прийняття правильних рішень зацікавленими суб'єктами.

Ключові слова: страхові компанії, фiнансова звітність, аналіз фінансового стану, платоспроможність страховика, фінансова стійкість.

Постановка проблеми. Ефективна діяльність фінансових посередників в економіці будь-якої країни вважається однією з ознак їі стабільного розвитку. На сьогодні в Україні склалася банкоцентрична модель фінансового ринку, однак, незважаючи на суттєве відставання за обсягами активів від банків-
Аннотация. Успешная деятельность страховщиков в значительной степени зависит от доверия к ним страхователей, которое растет при условии доступности и восприятия информаџии об их деятельности, которая отражается в финансовой отчетности, что является источником для аналитической оценки финансового состояния страховой компании на основе системы показателей, характеризующих ее финансовую устойчивость, надежность и платежеспособность, и предоставляет возможность принятия правильных решений заинтересованными субъектами.

Ключевые слова: cmpaховые компании, финансовая отчетность, анализ финансового состояния, платежеспособность страховщика, финансовая устойчивость.

ського сектору, небанківські фінансові установи, зокрема, страхові компанії, також можуть ефективно накопичувати та перерозподіляти фінансові ресурси на потреби економіки.

Розвиток вітчизняного страхового ринку значною мірою залежить від довіри страхувальників до страхових 
компаній, яка зростає за умови, коли страхові компанії є надійними та платоспроможними, а інформація щодо їхньої діяльності є доступною та зрозумілою для зацікавлених користувачів. Така інформація формується на основі даних обліку та подається у фінансовій звітності та звітних даних страховика. Від якості фінансової інформації залежить аналітична оцінка фінансової звітності страхової компанії та правильність прийнятих рішень зацікавленими суб'єктами.

Аналіз останніх досліджень та публікацій. Проблемні аспекти оцінки фінансового стану страхових компаній представлені у дослідженнях широкого кола праць як вітчизняних, так і зарубіжних науковців. Зокрема, питання фінансової стійкості, надійності та платоспроможності страховиків розглядали у наукових працях Аберніхіна І.Г., Сокиринська І.Г. [1], Гаманкова О.О. [2], Литвинов О.С. [3], Гончаренко О.О., Нагайчук Н.Г. [4], Ткаченко Н.В. [5] та ін. Не зважаючи на досить велику кількість досліджень даної проблематики, на сьогодні не існує єдиного підходу до оцінки фінансового стану страхових компаній на основі даних фінансової звітності, а тому потребують подальших досліджень науково-теоретичні аспекти аналізу фінансової звітності страховика, застосування його методичного інструментарію для оцінки фінансового стану страхової компанії та прогнозування iї діяльності на підставі даних фінансової звітності.

Метою статті $\epsilon$ теоретичне та методичне обгрунтування аналітичної оцінки фінансової звітності страхових компаній на основі системи показни- ків для забезпечення інтересів різних користувачів.

Виклад основного матеріалу. Страхова компанія $є$ специфічною небанківською фінансовою установою, яка концентрує на собі майнові інтереси своїх клієнтів (страхувальників). Тому основною метою організації фінансів страховика $є$ досягнення його стійкого фінансового стану, який $є$ результатом взаємодії всіх елементів фінансово-господарської діяльності страхової компанії і характеризується системою показників, що відображають наявність, розміщення і використання фінансових ресурсів страховика, та узагальнюються у звітності, необхідність формування якої, ऑiі види, склад, порядок, терміни подання, вимоги та методика заповнення визначено низкою законодавчо-нормативних актів.

Згідно Закону України «Про бухгалтерський облік і фінансову звітність в Україні» страхові компанії зобов'язані формувати фінансову звітність, метою складання якої $\epsilon$ надання користувачам для прийняття рішень повної, правдивої та неупередженої інформації про фінансовий стан та результати діяльності підприємства [6].

Користувачами фінансової звітності залежно від власних потреб щодо складу інформації $\epsilon$ безпосередньо (власники (засновники та акціонери), менеджери, інвестори, кредитори, банки, страхувальники, страхові посередники, перестраховики, цеденти, постачальники, державні органи) та опосередковано зацікавлені (аудитори, консалтингові фірми, фондові біржі, засоби масової інформації, асоціації, об'єднання страховиків, громадські 
організації, рейтингові агентства) фізичні та юридичні особи.

Фінансова звітність страховиків (проміжна та річна) повинна формуватись відповідно до вимог Міжнародних стандартів фінансової звітності, однак форми та склад фінансової звітності визначено Національним положенням (стандартом) бухгалтерського обліку 1 «Загальні вимоги до фінансової звітності»: баланс (звіт про фінансовий стан), звіт про фінансові результати (звіт про сукупний дохід), звіт про рух грошових коштів, звіт про власний капітал, примітки до фінансової звітності [7]. Слід зазначити, що цим положенням передбачено тільки форми і склад статей для перших чотирьох фінансових звітів, а примітки до фінансової звітності не формалізовано, оскільки останні є сукупністю показників і пояснень, які забезпечують деталізацію і обгрунтованість статей фінансової звітності, а також іншою інформацією, розкриття якої передбачено відповідними НП(С)БО або МСФ3.

У міжнародній практиці страховики складають лише фінансову звітність, проте, згідно з вимогами МСФЗ, іiі структура не є жорстко регламентованою, оскільки ці стандарти вимагають розкриття лише суттєвої інформації в необхідному обсязі. Таким чином, у фінансовій звітності страховики мають змогу розкривати не лише показники фінансово-майнового стану та результатів діяльності, а й специфічні дані щодо основної діяльності.

Крім фінансової звітності, за вимогами Національної комісії, що здійснює державне регулювання у сфері ринків фінансових послуг, страхова компанія повинна формувати звітні дані щодо здійснення страхової діяльності та розкриття іншої інформації, що стосується фінансового стану страховика [8], що містять: загальні відомості про страховика; звіт про доходи та витрати страховика; звіт про страхові платежі та виплати за структурними підрозділами страховика; пояснювальну записку до звітних даних страховика.

Разом із річною звітністю до Нацкомфінпослуг страховики подають інформацію щодо ключових ризиків та результатів проведеного стрестестування [9].

Звітність страховика $є$ інформаційною базою для проведення аналізу фінансового стану страхової компанії, якість якого залежить від якості представлення звітної фінансової інформації, яка повинна відповідати певним вимогам, що за вітчизняним законодавством визначені у НП(С)БО 1 «Загальні вимоги до фінансової звітності» (принципи та характеристики), в міжнародній практиці - у МСБО 1 «Подання фінансової звітності» [10] (принципи) та Концептуальній основі фінансової звітності [11] (якісні характеристики: доречність, правдиве подання, зіставність, можливість перевірки, зрозумілість).

Враховуючи основні напрями пруденційного нагляду Нацкомфінпослуг [12], аналітична оцінка фінансової звітності страхових компаній має відображати додержання страховиком встановлених критеріїв та нормативів щодо: ліквідності; капіталу та платоспроможності; прибутковості; якості активів та ризиковості операцій; якості систем управління та управлінсько- 
го персоналу; додержання правил надання фінансових послуг.

Таким чином, аналітична оцінка фінансової звітності страхової компанії буде формуватись, враховуючи результати аналізу динаміки та структури активів та пасивів страхової компанії; ліквідності та платоспроможності; фінансової стійкості; структури та динаміки доходів, витрат та фінансового результату страховика; рентабельності; руху грошових коштів; ризиковосTi.

На основі даних Балансу (Звіту про фінансовий стан) проводять аналіз динаміки та структури активів та пасивів страхової компанії, що дає можливість оцінити складові майна страховика та джерел його формування в динаміці i за структурою, тобто визначити зміну абсолютних величин та зміну питомої ваги показників.

Аналізуючи складові балансу страхової компанії, необхідно звернути увагу на співвідношення між дебіторською заборгованістю і чистим капіталом страховика, що якісно характеризує структуру активів страховика, відображаючи обсяг частково чи повністю не виконаних зобов'язань страхувальників перед страховою компанією, а також на співвідношення між загальною сумою зобов'язань і можливістю їх покриття власними активами, вільними від зобов'язань (тобто чистим капіталом). Також важливо визначити темп приросту чистого капіталу страховика, що може свідчити про зростання ринкової вартості страхової компанії, а також темп приросту величини чистих премій страховика протягом року.
Специфічним проявом надійності страховика $є$ його платоспроможність, що відображає здатність страховика сплачувати свої зобов'язання у будьякий момент часу i відіграє визначальну роль в оцінці фінансового стану. Показник платоспроможності ставиться на перше місце серед інших критеріїв надійності при складанні рейтингу страхових компаній. У більшості країн світу платоспроможність страховиків перебуває під контролем держави як гаранта інтересів страхувальників. Держава здійснює нагляд за дотриманням страховиками умов забезпечення платоспроможності шляхом перевірки встановлених законодавством правил i нормативів. Фінансовим забезпеченням платоспроможності виступають, як правило, два джерела: кошти страхових резервів і власні вільні кошти страховика.

В Україні вимоги до платоспроможності страховиків регулюються Законом України «Про страхування» (Розділ III «Забезпечення платоспроможності страховиків») [13] і концептуально корелюють 3 вимогами Директив Свропейського Союзу.

Відповідно до обсягів страхової діяльності страховики зобов'язані підтримувати належний рівень фактичного запасу платоспроможності вартісного показника, що показує співвідношення між зобов'язаннями страхової компанї та іï активами, що можуть бути використані для покриття цих зобов'язань. Визначається як різниця між загальною сумою активів (крім нематеріальних) і загальною сумою зобов'язань, у тому числі страхових (страхові зобов'язання прийма- 
ються рівними обсягам страхових резервів, які страховик зобов'язаний формувати) (табл. 1). Перевищення вар- тості активів над зобов'язаннями свідчить про наявність у страховика фактичного запасу платоспроможності.

Таблиця 1

Розрахунок показників платоспроможності для страховиків Фактичний запас платоспроможності (нетто-активи) (ФЗП): $\Phi 3 \Pi=A-H A-3$,

де $A$ - загальна сума активів; $H A$ - сума нематеріальних активів; 3 - загальна сума зобов'язань.

Розрахунковий нормативний запас платоспроможності для страховиків, що займаються іншими видами страхування, ніж страхування життя: обчислений на базі страхових премій: $\quad$ обчислений на базі страхових виплат: $H 3 \Pi 1=0,18(C \Pi-0,5 C \Pi \Pi)$ $H 3 П 2=0,26(C B-0,5 C B \Pi)$ де НЗП1 - нормативний запас платоспроможності;

СП - сума страхових премій за попередні 12 місяців (останній місяць буде складатися із кількості днів на дату розрахунку); СПП - сума страхових премій, переданих у перестрахування протягом звітного періоду де НЗП2 - розрахунковий запас платоспроможності;

$C B$ - сума страхових виплат за попередні 12 місяців (останній місяць буде складатися із кількості днів на дату розрахунку);

СВП - сума страхових виплат, компенсованих перестраховиками протягом звітного періоду

Розрахунковий нормативний запас платоспроможності для страховиків, що займаються страхуванням життя:

0,05 × Загальна величина резерву довгострокових зобов’язань (математичного резерву) Джерело: складено на основі [13]

За своїм економічним змістом фактичний запас платоспроможності являє собою чисті активи страховика, тобто власні кошти, вільні від зобов'язань (нетто-активи). Визначення цього показника є важливим через те, що страхова організація, страхувальники, державний наглядовий орган мають знати ті обсяги чистих ліквідних активів (власних коштів), якими володіс страховик і які можуть бути спрямовані на покриття страхових зобов'язань у випадку дефіциту коштів страхових резервів, що може виникнути $з$ огляду на характер страхової послуги, в основі якої лежить категорія страхового ризику: розрахунковий розмір страхових резервів може бути недостатнім для ви- конання всіх зобов'язань за страховими виплатами. Тому страховик повинен мати вільні від зобов'язань кошти, які може використати для виплат у разі, коли страхові резерви будуть вичерпані.

Слід зазначити, що показник фактичного запасу платоспроможності обчислюється однаково як для страховиків, що здійснюють страхування життя, так і для страховиків, що провадять загальне (ризикове) страхування, а показник нормативного запасу платоспроможності має певні особливості розрахунку залежно від видів страхування (життя/не життя) (див. табл. 1).

Для страховиків, що займаються іншими видами страхування, ніж 
страхування життя, розрахунковий нормативний запас платоспроможності має дорівнювати більшій 3 двох величин, одна 3 яких обчислюється на базі страхових премій (розраховується згідно із взятими страховими зобов'язаннями), а друга - на базі страхових виплат (розраховується згідно із виконаними страховими 30бов'язаннями). Після розрахунку обох передбачених законодавством величин нормативного запасу платоспроможності обирається більша 3 них і порівнюється 3 фактичним нормативним запасом. Економічний зміст такого порівняння полягає в тому, щоб визначити, наскільки обороти за страховими операціями страховика відповідають його фінансовим можливостям.

Для страховиків, що займаються страхуванням життя, розрахунковий нормативний запас платоспроможності визначається шляхом множення загальної величини резерву довгострокових зобов'язань (математичного резерву) на 0,05, тобто має становити 5\% величини резерву довгострокових зобов'язань (див. табл. 1). Загальна величина резерву довгострокових зобов'язань дорівнює сумі резервів довгострокових зобов'язань (математичних резервів), розрахованих на цю ж саму дату окремо за кожним договором страхування життя. Для таких розрахунків використовується інформація, що міститься в балансі та у звітних даних страховика.

Висновок щодо достатнього рівня платоспроможності страхових компаній роблять на підставі порівняння показників фактичного запасу платоспроможності 3 нормативним. Якщо фактичний запас платоспроможності перевищує розрахунковий нормативний запас платоспроможності, страхова компанія вважається платоспроможною, тобто власних коштів, вільних від зобов'язань, разом із страховими резервами має бути достатньо для виконання зобов'язань за страховими виплатами. Якщо страхова компанія має недостатній рівень платоспроможності, це може загрожувати їй прийняттям зі сторони наглядового органу передбачених законодавством санкцій аж до відкликання ліцензії на право здійснення страхової діяльності.

Слід зазначити, що вимоги щодо обов'язкових критеріїв i нормативів платоспроможності та достатності капіталу страховика також визначені Нацкомфінпослуг у Положенні про обов'язкові критерії і нормативи достатності капіталу та платоспроможності, ліквідності, прибутковості, якості активів та ризиковості операцій страховика (Розділ III) [14], відповідно до якого норматив платоспроможності та достатності капіталу визначається як сума прийнятних активів, яка на будьяку дату має бути не менше нормативного обсягу активів, що визначається як більша $з$ таких двох величин:

$$
3+K ; \text { або } 3+\text { НЗП, }
$$

де 3 - зобов'язання (величина довгострокових та поточних зобов'язань i забезпечень, що визначається як сумарна величина розділів II-IV пасиву Балансу (Звіту про фінансовий стан); $K$ - величина, що дорівнює: 30 млн. грн. - для страховика, який здійснює або планує здійснювати види страхування інші, ніж страхування життя; 45 млн. грн. - для страховика, який здійснює або планує здійснювати страху- 
вання життя; НЗП - нормативний запас платоспроможності, який розраховується відповідно до Закону України «Про страхування».

Крім розрахунку показників платоспроможності страховика, для повноти оцінки фінансового стану страхової компанії, аналізують відносні показники ліквідності балансу, що показу- ють здатність страховика швидко мобілізувати активи для покриття зовнішніх зобов'язань, щодо яких визначені теоретично обгрунтовані нормативні значення, відхилення від яких може свідчити про порушення платоспроможності страхової компанії та/або розрив платіжного балансу (табл. 2).

Таблиця 2

Відносні показники ліквідності балансу

\begin{tabular}{|c|c|c|}
\hline Показник & Формула розрахунку & Характеристика \\
\hline $\begin{array}{l}\text { k абсолют- } \\
\text { ної ліквідно- } \\
\text { сті }\left(k_{\text {АЛ}}\right)\end{array}$ & $\begin{array}{l}k_{\text {Ал }}=\frac{\Gamma E+\Pi \Phi I}{\text { пз }}, \\
\text { де ГЕ- гроші та їх еквіваленти; } \\
\text { ПФI- поточні фінансові інвес- } \\
\text { тиції; } \\
П 3-\text { поточні зобов'язання }\end{array}$ & $\begin{array}{l}\text { показує, яка частина поточних зо- } \\
\text { бов'язань може бути погашена за раху- } \\
\text { нок абсолютно ліквідних активів; умов- } \\
\text { но-нормативне значення > } 0,2\end{array}$ \\
\hline $\begin{array}{l}\text { k швидкої } \\
\text { ліквідності } \\
\left(k_{\text {Шл })}\right.\end{array}$ & $\begin{array}{l}k_{\text {шл }}=\frac{\Gamma Е+\Pi \Phi \mathrm{I}+д з}{\Pi з}, \\
\text { де Д3 - дебіторська заборгова- } \\
\text { ність }\end{array}$ & $\begin{array}{l}\text { показує, яка частина поточних зо- } \\
\text { бов’язань може бути погашена за раху- } \\
\text { нок абсолютно ліквідних активів та } \\
\text { можливих надходжень коштів; опти- } \\
\text { мальне значення } 1,0\end{array}$ \\
\hline $\begin{array}{l}\text { k поточнӧ̈ } \\
\text { ліквідності } \\
\left(k_{П л)}\right)\end{array}$ & $\begin{array}{l}k_{\text {пл }}=\frac{\mathrm{oA}}{\Pi 3} \\
\text { де } O A-\text { оборотні активи }\end{array}$ & $\begin{array}{l}\text { показує, якою мірою оборотні активи } \\
\text { покривають поточні зобов'язання; кри- } \\
\text { тичне значення } 1,0\end{array}$ \\
\hline
\end{tabular}

Джерело: складено на основі [15, с. 614]

Рівень фінансової стійкості є головним індикатором життєздатності страхової компанії та їі спроможності виконувати свої фінансові зобов'язання перед страхувальниками, тобто фінансова стійкість - це характеристика, що визначає стабільність фінансового стану страхової компанії, яка забезпечується високою часткою власного капіталу в загальній сумі фінансових ресурсів, що перебувають у розпорядженні страховика. Також фінансова стійкість $є$ індикатором рівня ризику діяльності страхової компанії та характеризує іiі залежність від залученого капіталу [4, с. 381].

При оцінюванні фінансової стійкості страховика використовують як традиційні, так і специфічні коефіцієнтні показники, що кількісно характеризують платіжні можливості страхувальника, синхронізацію його грошових потоків, структурну збалансованість інвестиційного портфеля та ін. (табл. 3). 
Таблиця 3

Показники фінансової стійкості страховика

\begin{tabular}{|c|c|}
\hline Показник, розрахунок & Характеристика показника \\
\hline $\begin{array}{r}k \text { фінансової незалежності (автономії): } \\
k_{\text {авт }}=\frac{\text { Власний капітал }}{\text { Валюта балансу }}\end{array}$ & $\begin{array}{l}\text { показує частку коштів, інвестова- } \\
\text { них у діяльність страховика його } \\
\text { власниками }\end{array}$ \\
\hline $\begin{array}{l}\text { k концентрації залученого капіталу: } \\
\qquad k_{\text {кзк }}=\frac{\text { Залучений капітал }}{\text { Валюта балансу }}\end{array}$ & $\begin{array}{l}\text { показує частку позикового } \\
\text { капіталу у загальній сумі його } \\
\text { джерел фінансування }\end{array}$ \\
\hline $\begin{array}{l}k \text { боргового навантаження: } \\
k_{\text {вн }}=\frac{\text { Зобов'язання }}{\text { Капітал }}\end{array}$ & $\begin{array}{l}\text { вказує на здатність страхової } \\
\text { компанії покрити зобов’язання } \\
\text { наявним капіталом }\end{array}$ \\
\hline 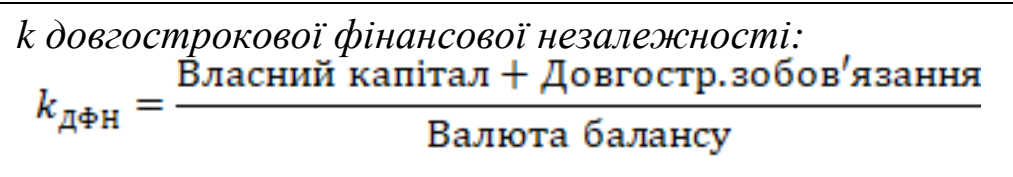 & $\begin{array}{l}\text { показує, якою мірою активи } \\
\text { сформовані за рахунок власного і } \\
\text { довгострокового позикового } \\
\text { капіталу }\end{array}$ \\
\hline $\begin{array}{l}k \text { відношення чистих страхових резервів до капіталу: } \\
\qquad k_{\mathrm{PK}}=\frac{\text { Чисті страхові резерви }}{\text { Чистий капітал }}\end{array}$ & $\begin{array}{l}\text { відображає достатність власних } \\
\text { засобів страхової компанії для } \\
\text { виконання її страхових зо- } \\
\text { бов’язань }\end{array}$ \\
\hline $\begin{array}{l}\text { k обсягів страхування (андерайтингу): } \\
k_{A}=\frac{\text { Страхові витрати і виплати }}{\text { Чисті зароблені страх. премії (або Страх. премії) }}\end{array}$ & $\begin{array}{l}\text { відображає активність страховика } \\
\text { щодо виплат за договорами } \\
\text { страхування й перестрахування }\end{array}$ \\
\hline $\begin{array}{l}\text { k оборотності кредиторської заборгованості за стра- } \\
\text { ховими виплатами: } \\
k_{\text {окз }}=\frac{\text { Кредитор. заборг. за страх.виплатами }}{\text { Чисті зароблені страхові премії }}\end{array}$ & $\begin{array}{l}\text { показує обсяг частково або по- } \\
\text { вністю не виконаних зобов'язань } \\
\text { страховика перед страхувальни- } \\
\text { ками }\end{array}$ \\
\hline $\begin{array}{l}\text { k незалежності від перестрахування: } \\
\quad k_{\text {нп }}=\frac{\text { Чиста сума премій за всіма полісами }}{\text { Валова сума премій за всіма полісами }}\end{array}$ & $\begin{array}{l}\text { вказує на ступінь фінансової не- } \\
\text { залежності страхової компанії від } \\
\text { перестраховиків }\end{array}$ \\
\hline $\begin{array}{c}k \text { покриття зобов'язань за страховими виплатами: } \\
k_{\text {пзсв }}=\frac{\text { Страхові резерви }+ \text { Капітал }}{\text { Страхові виплати }}\end{array}$ & $\begin{array}{l}\text { вказує на достатність страхових } \\
\text { резервів і капіталу для покриття } \\
\text { зобов'язань за страховими випла- } \\
\text { тами }\end{array}$ \\
\hline $\begin{array}{l}\text { k стійкості страхового фонду: } \\
k_{\text {сф }}=\frac{\text { Доходи за тариф.період + Кошти у запасн.фонд }}{\text { Витрати за тарифний період }}\end{array}$ & $\begin{array}{l}\text { Чим більший коефіцієнт, тим ви- } \\
\text { ще фінансова стійкість страхової } \\
\text { компанії }\end{array}$ \\
\hline
\end{tabular}
Джерело: складено на основі [1; 4; 5; 15]

Для визначення ступеня ймовірності дефіцитності коштів страхової компанії розраховують коефіцієнт Коньшина:

$$
k=\sqrt{(1-\mathrm{T}) / N \cdot T},
$$

де $T$ - середня тарифна ставка за всім страховим портфелем; $N$ - число застрахованих об’єктів.
Чим менше значення коефіцієнта Коньшина, тим більш фінансово стійкою є страхова компанія. Однак, варто зауважити, що цей коефіцієнт дає найточніші результати, якщо страховий портфель страховика складається 3 об'єктів 3 приблизно однаковими за вартістю ризиками (тобто без катастроф, землетрусів, загибелі космічних кораблів, літаків тощо). 
При оцінці фінансової стійкості страхової компанії використовується показник вартості чистих активів. Він може набувати як позитивного, так і від'ємного значення. Так, нормальною вважається ситуація, коли 3 часом вартість чистих активів збільшується порівняно 3 вартістю статутного капіталу. Зрозуміло, що при зростанні розміру власних коштів, наприклад за рахунок прибутку і подальшої його капіталізації, вартість чистих активів також зростає. У протилежній ситуації - зменшення величини власних коштів, наприклад при одержані збитків, вартість чистих активів також зменшується. Така ситуація є індикатором погіршення фінансового стану страховика і свідчить про те, що компанія витрачає більше, ніж заробляє. I той факт, що вартість чистих активів має від'ємне значення, свідчить про відсутність у страховика майна, достатнього для задоволення вимог кредиторів, та про незадовільний фінансовий стан страхової компанії, iii неплатоспроможність. Таким чином, якщо обсяг власного капіталу перевищує розмір статутного капіталу, це свідчить про прибуткову діяльність страхової компанії. Якщо розмір статутного капіталу є більшим за розмір власного капіталу, це характеризує діяльність страхової компанії як збиткову та показує заборгованість засновників стосовно сплати статутного капіталу. Чим вищий рівень сплаченого статутного капіталу, тим вищий рівень зацікавленості власників капіталу в розвитку страхової компанії [4, c. 382$]$.

На основі даних Звіту про сукупний дохід (Звіт про фінансові результати) та Звіту про доходи та витрати страховика можна провести порівняльний горизонтальний та вертикальний аналіз показників доходів, витрат та фінансових результатів страхової компанії, визначити абсолютні, відносні відхилення показників, а також провести структурний аналіз щодо складових доходів і витрат, та визначити їх вплив на фінансовий результат страховика. Таким чином, оцінюючи доходи, витрати та фінансові результати діяльності страховика, використовують систему абсолютних та відносних показників.

Аналіз доходів і витрат страховика дає змогу виявити причини дефіциту (профіциту) грошових коштів, визначення джерел їх надходження та напрямів їх витрачання для здійснення контролю за поточною платоспроможністю страховика. На основі даних Звіту про рух грошових коштів визначають відносні показники, що характеризують рух грошових коштів (табл. 4).

Слід зазначити, що чистий грошовий потік (ЧГП) визначається як різниця між надходженнями i витрачанням грошових коштів за аналізований період:

$$
\text { ЧГП = ПГП - НГП, }
$$

де ПГП - позитивний грошовий потік (сукупність надходжень грошових коштів від усіх видів операцій у страховому бізнесі); НГП негативний грошовий потік (сукупність виплат грошових коштів для здійснення всіх видів операцій у страховому бізнесі). 
Таблиця 4

Відносні показники, що характеризують рух грошових коштів страховика

\begin{tabular}{|c|c|c|}
\hline Показник & Розрахунок & Складові \\
\hline 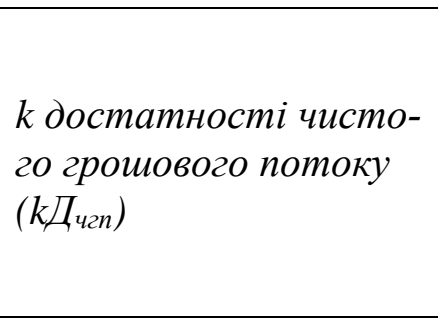 & $k Д_{\text {чrn }}=\frac{\text { ЧГП }}{\text { ОБ }}+$ Д & $\begin{array}{l}\text { ЧГП - чистий грошовий потік за визна- } \\
\text { чений період часу; } \\
O Б \text { - сума виплат основного боргу за } \\
\text { кредитами і позиками; } \\
\text { Д- сума дивідендів, що виплачені влас- } \\
\text { никам (акціонерам) на вкладений } \\
\text { капітал }\end{array}$ \\
\hline $\begin{array}{l}\text { k ліквідності грочово- } \\
\text { го потоку }\left(k Л_{2 n}\right)\end{array}$ & $k J_{\mathrm{rn}}=\Pi \Gamma \Pi-\frac{\left(\Gamma \mathrm{A}_{\mathrm{k}}-\Gamma \mathrm{A}_{\mathrm{n}}\right)}{\mathrm{H} \Pi}$ & $\begin{array}{l}\text { ПГП - позитивний грошовий потік; } \\
\Gamma A_{\kappa}-\text { залишок грошових активів на } \\
\text { кінець аналізованого періоду; } \\
\Gamma A_{n}-\text { залишок грошових активів на } \\
\text { початок аналізованого періоду; } \\
H Г П-\text { негативний грошовий потік (ви- } \\
\text { трачання грошових коштів) }\end{array}$ \\
\hline $\begin{array}{l}\text { k ефекттивності } \\
\text { грошового потоку } \\
\left(k \mathrm{E}_{\mathrm{rn}}\right)\end{array}$ & $k \mathrm{E}_{\mathrm{rn}}=\frac{\mathrm{\varphi Г \Pi}}{\mathrm{H \Gamma \Pi}}$ & $\begin{array}{l}\text { ЧГП - чистий грошовий потік за визна- } \\
\text { чений період часу; } \\
\text { НГП - негативний грошовий потік } \\
\text { (витрачання грошових коштів) }\end{array}$ \\
\hline $\begin{array}{l}\text { k реінвестування } \\
\text { чистого грошового } \\
\text { потоку }\left(k \mathrm{P}_{\text {чгп }}\right)\end{array}$ & $k \mathrm{P}_{\text {чाгा }}=$ чГП $-\frac{\text { Д }}{\Delta \mathrm{P}_{\mathrm{i}}}+\Delta \Pi_{\mathrm{i}}$ & $\begin{array}{l}\Delta P_{i}-\text { сума приросту реальних інвестицій } \\
\text { (у всіх їх формах) за аналізований } \\
\text { період; } \\
\Delta \Pi_{i}-\text { сума приросту портфельних } \\
\text { iнвестицій за аналізований період. }\end{array}$ \\
\hline
\end{tabular}

Джерело: складено на основі [4, с. 387]

Грошовий потік може бути як надлишковим (характеризує величину чистого грошового потоку, яка не використовується у страховому бізнесі), так i дефіцитним (такий грошовий потік, при якому надходження грошових коштів менше, ніж реальні потреби страховика у їх витрачанні).

Узагальнюючим показником ефективності діяльності страхової компанії в абсолютному значенні $є$ прибуток, відповідно відносним показником ефективності діяльності $є$ рентабельність, а також інші показники, що характеризують результативність страхової діяльності (табл. 5).
Оскільки страховий бізнес побудовано таким чином, що страхова компанія отримує грошові кошти перш, ніж зробити послугу, а виплати відбуваються за страховими випадками через деякий час, це дає можливість страховій компанії акумулювати значні суми у себе на рахунках та інвестувати їх. Саме тому дохід від інвестиційної діяльності може значно перевищувати дохід від операцій по страхуванню. В той же час, неправильне управління інвестиціями може стати причиною значних збитків, навіть більших, ніж збитки від операційної діяльності, що в кінцевому рахунку може призвести до банкрутства страхової компанії [3, с. 3-5]. 
Таблиця 5

Показники, що характеризують результативність страхової діяльності

\begin{tabular}{|c|c|}
\hline Показник & Розрахунок \\
\hline Рентабельність активів $\left(R_{A}\right)$ & $R_{A}=\frac{\text { Прибуток чистий }}{\text { Cередньорічна вартість активів }}$ \\
\hline Рентабельність витрат $\left(R_{B}\right)$ & $R_{B}=\frac{\text { Прибуток чистий }}{\text { Витрати }}$ \\
\hline $\begin{array}{l}\text { Рентабельність власного капіталу } \\
\left(R_{B K}\right)\end{array}$ & $R_{B K}=\frac{\text { Прибуток чистий }}{\text { Власний капітал }}$ \\
\hline $\begin{array}{l}\text { Рентабельність інвестиційної діяль- } \\
\text { ності }\left(R_{I}\right)\end{array}$ & $R_{I}=\frac{\text { Прибуток від інвест, }- \text {-ті }}{\text { Страхові резерви }}$ \\
\hline k ризику страхування $\left(k_{P C}\right)$ & $k_{\mathrm{PC}}=\frac{\text { Чneтi премії за всіма полісами }}{\text { Чиетий капітал }}$ \\
\hline$k$ рівня витрат $\left(k_{\mathrm{PB}}\right)$ & $k_{\mathrm{PB}}=\frac{\text { Витрати }}{\text { Страхові премії - Операції з перестрахування }}$ \\
\hline
\end{tabular}

Джерело: складено на основі [1; 4; 15]

В теорії інвестицій об'єктом для вивчення $\epsilon$ портфель інвестиційних вкладень (вклади в цінні папери, нерухомість, депозити в банках, матеріальні цінності). При цьому кожна інвестиція характеризується параметрами доходності за рік: збільшення вартості і дохід від володіння такою інвестицією (отримані дивіденди, доходи за процентними ставками, чистий прибуток за період). Але також кожна інвестиція характеризується показниками «просадки» за рік, тобто скільки можна втратити протягом року у разі невдалого інвестування. При цьому кожний інвестор визначає для себе максимальний рівень «просадки», який він може собі дозволити, так званий рівень толерантності до ризику. Тому цікаво розглянути показники ефективності вкладень 3 урахуванням ризику для правильного інвестування засобів в різні активи (Таблиця 6).

Одним із аналітичних інструментів вимірювання потенційного впливу на фінансовий стан страховика виняткових, але ймовірних подій (стресів), що можуть вплинути на діяльність страховика, є тести раннього попередження, що повинні регулярно проводитись страховою компанією та подаватись за визначеною формою разом із річною звітністю до Нацкомфінпослуг [9].

Ключовими ризиками для страхових компаній Нацкомфінпослуг називає 12 можливих стресових подій:

- зменшення на 30\% ринкової вартості акцій, які перебувають у лістингу на фондовій біржі, що включені до складу активів балансу;

- зменшення на 40\% ринкової вартості акцій, які не перебувають у лістингу, що включені до складу активів балансу;

- зниження на 10\% цін на облігації підприємств, що включені до складу активів балансу;

- підвищення обмінного курсу іноземних валют відносно гривні на 25\%;

- зниження обмінного курсу іноземних валют відносно гривні на 25\%;

- зниження ринкових цін на нерухомість на $25 \%$; 
Таблиця 6

Показники ризиковості інвестиційної діяльності страховика

\begin{tabular}{|c|c|c|}
\hline Показник & Розрахунок показника & Характеристика показника \\
\hline $\begin{array}{l}\text { k Wapna } \\
\left(k_{\text {Sharpe }}\right)\end{array}$ & $\begin{array}{l}k_{\text {Sharpe }}=\frac{R_{p}-R_{f}}{\delta_{p}}, \\
\text { де } R_{p}-\text { доходність інвестицій; } \\
R_{f}-\text { доходність безризикової інвес- } \\
\text { тиції; } \\
\delta_{p}-\text { середньоквадратичне відхилен- } \\
\text { ня доходності інвестицій. }\end{array}$ & $\begin{array}{l}\text { Оцінює якість інвестиційної } \\
\text { стратегії та використовується для } \\
\text { оцінювання, наскільки прибутко- } \\
\text { вість активу компенсує ризик, що } \\
\text { приймається інвестором. } \\
\text { Що менший } k \text {, то менший ризик } \\
\text { інвестування, але і менша доход- } \\
\text { ність страхової компанії. }\end{array}$ \\
\hline $\begin{array}{l}\text { k інформацій- } \\
\text { ного співвідно- } \\
\text { шення } \\
\text { (Information } \\
\text { Ratio) }\end{array}$ & $\begin{array}{l}k_{I R}=\frac{R_{p}-R_{b}}{\delta\left(R_{p}-R_{b}\right)}, \\
\text { де } R_{b}-\text { доходність базової інвестиції; } \\
\delta\left(R_{p}-R_{b}\right)-\text { середньоквадратичне } \\
\text { відхилення різниці доходностей інве- } \\
\text { стиції по відношенню до базової }\end{array}$ & $\begin{array}{l}\text { Характеризує співвідношення } \\
\text { доходності базової інвестиції до } \\
\text { середньоквадратичного відхи- } \\
\text { лення різниці доходностей інвес- } \\
\text { тиції по відношенню до базової }\end{array}$ \\
\hline $\begin{array}{l}\text { k співвідношен- } \\
\text { ня доходності } \\
\text { інвестицій до } \\
\text { капіталу з ура- } \\
\text { хуванням ризи- } \\
\text { ку (Risk } \\
\text { adjusted return } \\
\text { on capital, } \\
\text { RAROC) }\end{array}$ & $\begin{array}{l}R A R O C=\frac{R_{p}}{V A R_{p}}, \\
\text { де VAR }- \text { необхідний капітал з ура- } \\
\text { хуванням ризику, необхідний для } \\
\text { даної інвестиції (із заданим рівнем } \\
\text { ймовірності нерозорення). }\end{array}$ & $\begin{array}{l}\text { Характеризує співвідношення } \\
\text { доходності інвестицій до необхі- } \\
\text { дного капіталу з урахуванням } \\
\text { ризику, необхідний для даної } \\
\text { інвестиції із заданим рівнем ймо- } \\
\text { вірності нерозорення }\end{array}$ \\
\hline $\begin{array}{l}\text { k співвідношен- } \\
\text { ня доходності } \\
\text { активу до мак- } \\
\text { симального } \\
\text { падіння (RO- } \\
\text { MAD) }\end{array}$ & $\begin{array}{l}R O M A D=\frac{R_{p}}{\max D R D}, \\
\text { де maxDRD - максимально можливе } \\
\text { падіння вартості активу за період, що } \\
\text { розглядається }\end{array}$ & $\begin{array}{l}\text { Характеризує співвідношення } \\
\text { доходності активу до максималь- } \\
\text { но можливого падіння вартості } \\
\text { активу за аналізований період }\end{array}$ \\
\hline
\end{tabular}

Джерело: складено на основі [3, с. 3-5]

- збільшення загальної суми виплат за обов'язковим страхуванням цивільно-правової відповідальності власників наземних транспортних засобів страхування на 30\% (для страховиків, що здійснюють таке страхування);

- збільшення загальної суми виплат за медичним страхуванням (безперервним страхуванням здоров'я) на 40\% (для страховиків, що здійснюють таке страхування);

- збільшення витрат, пов'язаних 3 обслуговуванням договорів медичного страхування (безперервного страхування здоров'я), на 10\% (для страховиків, що здійснюють таке страхуванНя);

- збільшення рівня смертності для кожної вікової групи на 15\% (для страховиків, що здійснюють страхування життя);

- зменшення рівня смертності для кожної вікової групи на 20\% (для страховиків, що здійснюють страхування життя); 
- збільшення рівня тимчасової втрати працездатності, інвалідності, отримання травматичних ушкоджень, функціональних розладів здоров'я на 35\% у перший рік дії договорів страхування та збільшення рівня тимчасової втрати працездатності, інвалідності, отримання травматичних ушкоджень, функціональних розладів здо-

$$
\triangle B H A^{i}, \text { грн. }=B H A_{3}-B H A_{c}^{i}
$$

ров'я на $25 \%$ протягом наступних років дії договорів страхування (для страховиків, що здійснюють страхування життя).

Результатом проведеного стрестестування $є$ зміна величини неттоактивів як в абсолютному значенні (грн.), так і у відсотках:

де $B H A_{3}$ - загальна величина нетто-активів відповідно до звітних даних страховика, грн.; $B H A^{i}{ }_{c}$ - величина нетто-активів, оцінених згідно з припущенням, що описує $i$-ту стресову подію, грн. $(i=\overline{1 ; n}, n-$ кількість стресових подій $(n=12))$

Висновки. Фінансова звітність показників, що характеризують іiі фістрахових компаній повинна відображати особливості їх діяльності на потребу зацікавлених користувачів. Пошук сучасних методів загальної оцінки фінансово-господарської діяльності страхової компанії на основі системи нансову стійкість, надійність та платоспроможність уможливлюють надання багатогранної аналітичної оцінки звітності страхової компанії для формування вмотивованих аналітичних висновків.

\section{Список використаної літератури}

1. Аберніхіна І.Г., Сокиринська І.Г. Система показників оцінки фінансової надійності страховика. Фінанси України. 2017. №6. С. 74-86. URL: http://nbuv.gov.ua/UJRN/Fu_2017_6_7 (дата звернення 10.12.2019).

2. Гаманкова О.О. Фінансова стійкість та платоспроможність страхової організації. Вісник Київського національного університету імені Тараса Шевченка. Економіка. 2007. №94-95. С. 18-23.

3. Литвинов О.С. Инвестиционные риски страховой компании. Страховое дело. 2013. С. 3-23.

4. Нагайчук Н.Г., Гончаренко О.О. Фінанси страхових компаній : навч. посіб. Київ : УБС НБУ, 2010. 527 с.

5. Ткаченко Н.В. Фінансова стійкість страхових компаній (методологія оцінки та механізми забезпечення): автореф. дис. на здобуття наук. ступеня д-ра екон. наук: 08.00.08. ДВНЗ «Укр. акад. банк. справи Нац. банку України». Суми, 2011.33 с. 
6. Про бухгалтерський облік і фінансову звітність в Україні : Закон України від 16 липня 1999 р. № 996-XIV. URL: http://zakon2.rada.gov.ua/laws/show/99614 (дата звернення 10.12.2019).

7. Національне положення (стандарт) бухгалтерського обліку 1 «Загальні вимоги до фінансової звітності» : Наказ МФУ від 07 лютого 2013 р. № 73. URL: https://zakon.rada.gov.ua/laws/show/z0336-13 (дата звернення: 10.12.2019).

8. Порядок складання звітних даних страховиків : Розпорядження Держкомфінпослуг від 03 лютого 2004 p. № 39. URL: https://zakon.rada.gov.ua/laws/show/z0517-04 (дата звернення: 10.12.2019).

9. Вимоги щодо регулярного проведення стрес-тестування страховиками та розкриття інформації щодо ключових ризиків та результатів проведених стрестестів : Розпорядження Нацкомфінпослуг від 13 лютого 2014 р. № 484. URL: https://zakon.rada.gov.ua/laws/show/z0352-14\#n17 (дата звернення: 10.12.2019).

10. Міжнародний стандарт фінансової звітності 1 «Подання фінансової звітності». URL: http://zakon5.rada.gov.ua/laws/show/929_013 (дата звернення: 10.12.2019).

11. Концептуальна основа фінансової звітності / Міжнародний документ від 01 вересня 2010 p. URL: https://zakon.rada.gov.ua/laws/main/929_009 (дата звернення: 10.12.2019).

12. Про фінансові послуги та державне регулювання ринків фінансових послуг : Закон України від 12 липня 2001 p. № 2664-III. URL: http://zakon3.rada.gov.ua/laws/show/2664-14 (дата звернення: 10.09.2019).

13. Про страхування : Закон України від 07 березня 1996 р. № 85/96-BP. URL: https://zakon.rada.gov.ua/laws/show/85/96-\%D0\%B2\%D1\%80 (дата звернення 10.12.2019).

14. Положення про обов'язкові критерії і нормативи достатності капіталу та платоспроможності, ліквідності, прибутковості, якості активів та ризиковості операцій страховика : Розпорядження Нацкомфінпослуг від 07 червня 2018 р. № 850. URL: https://zakon.rada.gov.ua/laws/show/z0782-18 (дата звернення: 10.12.2019).

15. Савицька Г.В. Економічний аналіз діяльності підприємства : навч. посіб. Київ : Знання, 2007. 668 с. 